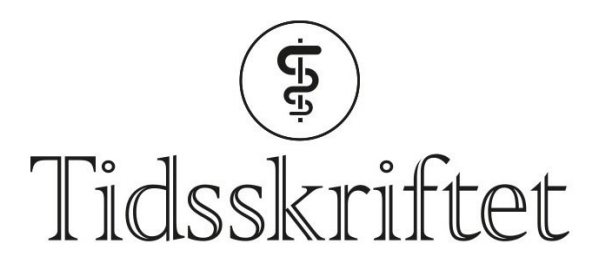

DEN NORSKE LEGEFORENING

\title{
Knut Ivar Iversen
}

MINNEORD

MARTIN SCHUSTER

ANNELISE FREDRIKSEN

RIGMOR MOELV

BJØRN RAFTER

PER A. ELLINGSEN

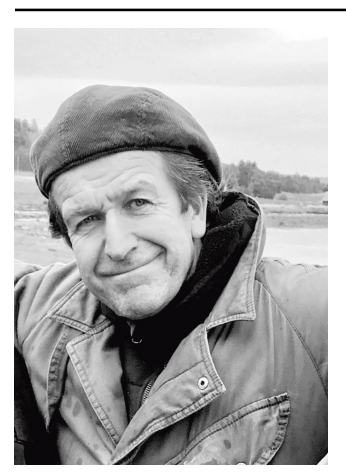

Vår gode kollega og venn, spesialist i psykiatri Knut Ivar Iversen, gikk bort 22.8.2019, 65 år gammel, etter kort tids sykeleie. Bare 8 uker i forveien hadde vår kollegagruppe sin tradisjonelle sommeravslutning, og vi ble enige om en ny felles reise til Malaga til høsten. Lite ante verken vi eller Knut Ivar om at det skulle bli siste gang vi møttes.

Knut Ivar var en ekte tromsøgutt. Han utdannet seg som programingeniør i NRK i Oslo før han flyttet tilbake til Troms $\emptyset$, der han ble ferdigutdannet lege i 1985 og spesialist i psykiatri i 1992. Det var gjennom jobben han møtte Catharina som han stiftet familie med. Familien var i alle år Knut Ivar sitt viktigste anker.

Knut Ivar var sterkt engasjert i faget og tok videreutdanning i psykoanalytisk psykoterapi, gruppeanalyse, kognitiv terapi og psykoterapi ved psykose. I 1990-årene var Knut Ivar klinikkleder ved Åsgård sykehus. Han var engasjert i oppbyggingen av Viken senter for psykiatri og sjelesorg i Bardu tidlig på 20oo-tallet og fungerte her som leder av enheten for forsknings- og utviklingsarbeid.

Siste halvdel av sitt yrkesliv arbeidet Knut Ivar i første rekke som avtalespesialist i psykiatri i Troms $\emptyset$. Som godkjent psykoterapiveileder fulgte han mange leger fra Nord-Norge i deres spesialisering i psykiatri. I 2008 disputerte han med sin doktoravhandling om tvangsbruk i 
psykisk helsevern.

Han var aktiv i Nordnorsk psykoterapiforum og deltok siden 1990-årene i en kollegagruppe i Tromsø bestående av privatpraktiserende psykiatere og senere psykologspesialister. Her ble vi godt kjent med Knut Ivar, ble inspirert av hans kunnskap og satte pris på hans romslighet og lune humor.

Knut Ivar hadde også helt andre talenter. I 1970-årene drev han med banekjøring med bil på nasjonalt nivå, og mange år senere kjøpte han tilbake bilen som han brukte mye tid på å restaurere. Han fant også stor glede i å snekre og var ikke redd for å igangsette ambisiøse byggeprosjekter både hjemme og på familiens landsted på Senja. De senere årene oppfylte han en gammel drøm og tok fatt på å ta flysertifikat.

Våre tanker går i første rekke til hans kone Catharina og barna Henrik, Rosa og Ulrik, som har mistet en ektefelle og en far som verdsatte familien så høyt. Det er sårt ikke å ha Knut Ivar med videre i vår kollegagruppe, og han vil bli savnet av mange pasienter og kolleger. Vi lyser fred over hans minne.

Publisert: 16. mars 2020. Tidsskr Nor Legeforen. DOI: 10.4045/tidsskr.20.0092

(C) Tidsskrift for Den norske legeforening 2020. Lastet ned fra tidsskriftet.no 